\title{
Effects of pretreatment with microbial phytase on phosphorous utilization and growth performance of Nile tilapia (Oreochromis niloticus)
}

\author{
L. CAO ${ }^{1,3}$, Y. YANG ${ }^{2,3}$, W.M. WANG ${ }^{1}$, A. YAKUPITIYAGE ${ }^{3}$, D.R. YUAN ${ }^{3}$ \& J.S. DIANA ${ }^{4}$ \\ ${ }^{1}$ College of Fishery, Key Lab of Agricultural Animal Genetics, Breeding and Reproduction of Ministry of Education, Huazhong \\ Agricultural University, Wuhan, Hubei, China; ${ }^{2}$ College of Aqua-Life Science and Technology, Shanghai Fisheries University, \\ Shanghai, China; ${ }^{3}$ Aquaculture and Aquatic Resources Management, School of Environment, Resources and Development, \\ Asian Institute of Technology, Pathum Thani, Thailand; ${ }^{4}$ School of Natural Resources and Environment, University of \\ Michigan, Ann Arbor, MI, USA
}

\section{Abstract}

This study was to assess effects of the pretreatment in allplant based diets with microbial phytase on phosphorous utilization and growth performance of Nile tilapia (Oreochromis niloticus). Pretreatment trials were conducted using phytase at graded doses to determine the optimal dose of phytase. Available phosphorus (P) levels increased significantly with the increased doses of phytase and the dose of $1000 \mathrm{U} \mathrm{kg}^{-1}$ was most efficient. Based on the pretreatment trials, plant based diets for Nile tilapia were formulated by pretreating with phytase at $1000 \mathrm{U} \mathrm{kg}^{-1}$. Experimental diets were supplemented with graded levels of mono calcium phosphate (MCP) at 25, 18.75, 12.5, 6.25 and $0 \mathrm{~g} \mathrm{~kg}^{-1}$ diet. In addition, there were three controls: one phytase control, one inorganic $\mathrm{P}$ control and one pretreatment control. The results showed that diets pretreated with phytase gave better growth performance, feed conversion ratio and protein efficiency ratio of Nile tilapia compared with the phytase control diet and pretreatment control diet $(P<0.05)$. There were no significant differences in growth performance of Nile tilapia between the inorganic control diet and phytase pretreated diets supplemented with $\mathrm{MCP}$ at $25,18.75$ and $12.5 \mathrm{~g} \mathrm{~kg}^{-1}$ $(P>0.05)$, which resulted in significantly better performance than those at 6.25 and $0 \mathrm{~g} \mathrm{~kg}^{-1}(P<0.05)$. Dietary interaction effects of phytase were observed for phosphorus retention efficiency and phosphorus load. Apparent digestibility coefficient of $\mathrm{P}$ (ADCp) was improved significantly by phytase pretreatment $(P<0.05)$. No significant difference was detected on ADC of crude protein among all experimental diets $(P>0.05)$.
KEY WORDS: digestibility, growth, microbial phytase, Nile tilapia Oreochromis niloticus, phosphorous, phytate

Received 1 February 2007, accepted 21 May 2007

Correspondence: Yi Yang, College of Aqua-Life Science and Technology, Shanghai Fisheries University, 334 Jun Gong Road, Shanghai 200090, China. (E-mail: yiyang@shfu.edu.cn)

\section{Introduction}

Currently, there are increasing interests in the complete replacement of fish meal by various grain products, such as soybean meal, wheat flour and corn gluten meal (Cain \& Garling 1995). One of the major problems limiting the use of grain products in fish feed is the presence of phytate (inositol hexaphosphate). Phytate is the primary form of phosphorus $(\mathrm{P})$ in grains, accounting for approximately two-thirds of the total P bound as phytate P (Lall 1991). Phytate is an indigestible $\mathrm{P}$ form, which is practically not available for fish such as tilapias [NRC (National Research Council) 1993] because of lack of an intestinal phytase for efficient hydrolysis of phytate during digestion (Jackson et al. 1996). Consequently, the available $\mathrm{P}$ in all-plant diets may not meet the requirements of fish, and inorganic $\mathrm{P}$ is usually supplemented to the diets. On the other hand, undigested phytate $\mathrm{P}$ excreted via faeces and contributes to environmental pollution, causing eutrophication in receiving water bodies.

Exogenous phytase has been used successfully to hydrolyse phytate and increase nutrient digestibility (Cao et al. 2007). Specifically for hydrolysis of phytate, phytase is most promising in producing cost-effective fish feed formula that can reduce the need to supplement of inorganic $\mathrm{P}$ in feeds and also lower 
phytate P levels in fish excretion (Simons et al. 1990; Liener 1994). Phytase is not heat stable and should be applied by avoiding excess heat during extrusion and other steps in diet manufacture (Vielma et al. 2002). It is deactivated at temperatures above $65^{\circ} \mathrm{C}$, while the temperature during feed processing often exceeds $65^{\circ} \mathrm{C}$ (Cao et al. 2007). Phytase can be utilized in fish feeds by pretreating feedstuffs (Cain \& Garling 1995), or spraying onto pellets (Vielma et al. 2004) to avoid deactivation.

Studies on the role of supplemental phytase for nutrient utilization or growth of fish focus on commonly cultured species, such as rainbow trout (Oncorhynchus mykiss) (Rodehutscord \& Pfeffer 1995; Forster et al. 1999), common carp (Cyprinus carpio L.) (Schäfer et al. 1995), channel catfish (Ictalurus punctatus) (Jackson et al. 1996; Li \& Robinson 1997) and Nile tilapia (Oreochromis niloticus) (Furuya et al. 2001; Liebert $\&$ Portz 2005). Biological factors such as the rearing temperature of fish may influence the function of phytase applied onto a diet. Thus, pretreatment seems to be more promising than topspraying as the dephytinization process happens in vitro of fishes. As a result of the increasing price and decreasing resources, inorganic $\mathrm{P}$ supplementation in fish diets could be replaced partially or fully by phytase (Cao et al. 2007).

However, there have been inconsistent results from studies evaluating the effects of phytase pretreatment on feed quality and utilization. Cain \& Garling (1995) reported that pretreatment of soybean meal with phytase enhanced growth performance and $\mathrm{P}$ utilization of juvenile rainbow trout. Similarly, dephytinization of soy protein concentrate increased protein and $\mathrm{P}$ utilization in Atlantic salmon in seawater (Storebakken et al. 1998), whereas a decrease in rapeseed protein quality by dephytinization was noted by Teskeredzic et al. (1995) in rainbow trout. Results related to weight gain, apparent digestibility of crude protein and amino acids after phytase addition also showed great inconsistency (Sajjadi \& Carter 2004). Some studies found that addition of phytase had positive effects on weight gain of rainbow trout (Rodehutscord \& Pfeffer 1995; Vielma et al. 1998) and channel catfish (Jackson et al. 1996; Li \& Robinson 1997), while other studies detected no effects for the same species (Lanari et al. 1998; Yan $\&$ Reigh 2002). Many studies have demonstrated that addition of phytase to fish feeds can improve the utilization of phytate $\mathrm{P}$ and decrease the total $\mathrm{P}$ load to the environment for several species (Vielma et al. 1998; Liebert \& Portz 2005).

In Nile tilapia, phytase supplementation between 500 and $1500 \mathrm{U} \mathrm{kg}^{-1}$ improved $\mathrm{P}$ availability, crude protein digestibility and bone mineralization (Furuya et al. 2001). Liebert $\&$ Portz (2005) reported that phytase supplementation of $750 \mathrm{U} \mathrm{kg}^{-1}$ in Nile tilapia diets resulted in the same performance as inorganic $\mathrm{P}$ addition $\left(\mathrm{NaH}_{2} \mathrm{PO}_{4} ; 15 \mathrm{~g} \mathrm{~kg}^{-1}\right.$ diet $)$.
The available $\mathrm{P}$ requirement of Nile tilapia is between 5 [NRC (National Research Council) 1993] and $9 \mathrm{~g} \mathrm{~kg}^{-1}$ (Watanabe et al. 1980; Beveridge \& McAndrew 2000), and tilapia juveniles usually need higher $\mathrm{P}$ levels than adults. When all-plant diets are used, total $\mathrm{P}$ content from plant ingredients is usually less than that in fishmeal-based diets. Thus, $\mathrm{P}$ content in all-plant diets may not meet the $\mathrm{P}$ requirement of Nile tilapia juveniles and partial supplementation of inorganic P may be needed. Whether inorganic P supplementation could be partially or completely replaced in Nile tilapia feed needs further investigation. Besides, the approximate amount of phytate $\mathrm{P}$ converted to available $\mathrm{P}$ in plant ingredients after phytase pretreatment is also uncertain.

The purposes of this study was to determine the optimal dose of phytase for pretreatment of plant ingredients and the amount of available $P$ released from phytate $P$, to investigate the effects of the phytase pretreatment and replacement levels of inorganic $\mathrm{P}$ on growth performance as well as apparent digestibility of crude protein and $\mathrm{P}$ of Nile tilapia juveniles fed all-plant diets.

\section{Materials and methods}

\section{Pretreatment trials}

Two pretreatment trials were conducted using a completely randomized design at the Asian Institute of Technology (AIT), Thailand, from 5 January to 5 February 2006. In the first trial, soybean meal was treated with microbial phytase (Habio ${ }^{\circledR}$ Phytase-5000 FTU g ${ }^{-1}$, Sichuan Habio Bioengineering Co. Ltd, Chengdu, Sichuan, China) at 0 (control), 500, 750, 1000 and $1500 \mathrm{U} \mathrm{kg}^{-1}$. The second trial was conducted to treat mixed plant meal consisting of soybean meal $\left(644 \mathrm{gKg}^{-1}\right)$, wheat meal $\left(119 \mathrm{gKg}^{-1}\right)$ and corn gluten meal $\left(237 \mathrm{gKg}^{-1}\right)$ with phytase at 0 (control), 500, 750, 1000, 1500 and $3000 \mathrm{U} \mathrm{kg}^{-1}$. Each treatment had three replicates. The pretreatment method described by Cain \& Garling (1995) was used and adapted in the present study. The procedures of the method were to: (i) prepare $0.2 \mathrm{M}$ citrate buffer (dissolve $15.38 \mathrm{~g}$ citric acid and $37.29 \mathrm{~g}$ sodium citrate into 1-L distilled water) at room temperature; (ii) dissolve $2 \mathrm{~g}$ phytase (5000 $\mathrm{U} \mathrm{g}^{-1}$ ) into 1-L citrate buffer using a magnetic stirrer for 30 min; (iii) add meal to the buffer at $1: 1$ (w : v), and place the mixture in aluminum trays and rapidly heat with constant stirring to $50-55{ }^{\circ} \mathrm{C}$ (cover the mixture with aluminum foil and incubate at $55^{\circ} \mathrm{C}$ for $6 \mathrm{~h}$ ); (iv) dry the mixture in a forced-air drying oven at $60{ }^{\circ} \mathrm{C}$ for $24 \mathrm{~h}$ to reduce the moisture content to approximately $100 \mathrm{gKg}^{-1}$. In the control, the same method was used but without adding phytase (Riche et al. 2001). 


\section{Experimental diets}

Experimental design and basal diet formulations were based on the assumption that effects of phytase pretreatment can be most accurately measured using $\mathrm{P}$ utilization as the indicator of phytic acid hydrolysis (Vielma et al. 1998). Therefore, an all-plant basal diet was formulated to contain low levels of available P (Table 1).

Five treatment diets were supplemented with mono calcium phosphate (MCP) at $25 \mathrm{~g} \mathrm{~kg}^{-1}(100 \%$ MCP supplement, diet 3), $18.75 \mathrm{~g} \mathrm{~kg}^{-1}$ (75\% MCP supplement, diet 4), $12.5 \mathrm{~g} \mathrm{~kg}^{-1}$ (50\% MCP supplement, diet 5), $6.25 \mathrm{~g} \mathrm{~kg}^{-1}$ (25\% MCP supplement, diet 6) and $0 \mathrm{~g} \mathrm{~kg}^{-1}(0 \% \mathrm{MCP}$ supplement, diet 7) respectively, by cassava replacement for different experimental treatments (Table 2). In addition, there were three controls: one phytase control (diet 1, basal diet) with neither phytase pretreatment nor inorganic $\mathrm{P}$ supplement; one inorganic $\mathrm{P}$ control (diet 2) without phytase pretreatment but with $25 \mathrm{~g} \mathrm{~kg}^{-1}$ supplement of MCP by replacing the same amount of cassava starch in the basal diet;

Table 1 Composition of the basal diet for Nile tilapia juveniles

\begin{tabular}{|c|c|}
\hline Ingredients & As-fed basis $\left(\mathrm{g} \mathrm{kg}^{-1}\right)$ \\
\hline Soybean meal (oil-extracted) & 536.5 \\
\hline Wheat & 100.0 \\
\hline Corn gluten meal & 200.0 \\
\hline Cassava & 103.5 \\
\hline Mineral premix ${ }^{1}$ & 10.0 \\
\hline Fish oil & 35.0 \\
\hline Soy lecithin & 10.0 \\
\hline Vitamin premix ${ }^{2}$ & 5.0 \\
\hline Total & 1000.0 \\
\hline Proximate analysis & Dry matter basis $\left(\mathrm{g} \mathrm{kg}^{-1}\right)$ \\
\hline Moisture & 109.1 \\
\hline Crude protein & 363.8 \\
\hline Crude lipid & 57.1 \\
\hline Fibre & 28.2 \\
\hline Ash & 51.0 \\
\hline Nitrogen-free extract ${ }^{3}$ & 499.9 \\
\hline Calcium & 2.0 \\
\hline Total P & 4.5 \\
\hline Phytate P & 3.0 \\
\hline Available $\mathrm{P}^{4}$ & 1.5 \\
\hline
\end{tabular}

\section{$\mathrm{P}$, phosphorus.}

${ }^{1}$ Mineral premix (per $\mathrm{kg}$ of diet): $\mathrm{MnSO}_{4}, 54 \mathrm{mg}$; ferric citrate, $142 \mathrm{mg} ; \mathrm{CuSO}_{4}, 10 \mathrm{mg} ; \mathrm{ZnCO}_{3}, 29 \mathrm{mg}$; $\mathrm{NaCl}, 3.3 \mathrm{mg} ; \mathrm{KI}, 0.9 \mathrm{mg}$; $\mathrm{K}_{2} \mathrm{SO}_{4}, 90 \mathrm{mg}$; $\mathrm{CoCl}, 0.21 \mathrm{mg} ; \mathrm{MgO}, 10 \mathrm{mg}$.

${ }^{2}$ Vitamin premix Roche 2118 (Hoffman-La Roche, Inc., Nutley, NJ, USA) (per kg of diet): Vitamin A, 12000 UI; Vitamin $D_{3}, 5000$ UI; Vitamin $E_{1} 30 \mathrm{mg}$; Vitamin $\mathrm{K}_{3}, 3 \mathrm{mg}$; Vitamin $\mathrm{B}_{1}, 2.2 \mathrm{mg}$; Vitamin $\mathrm{B}_{2}, 8 \mathrm{mg}$; Vitamin $\mathrm{B}_{6}, 5 \mathrm{mg}$; Vitamin $\mathrm{B}_{12}, 11 \mathrm{mg}$; Folic acid, $1.5 \mathrm{mg}$; Biotin, $150 \mathrm{mg}$; Pantothenic acid: $25 \mathrm{mg}$; inositol, $65 \mathrm{mg}$.

${ }^{3}$ Calculated as: NFE $=[1000-($ moisture + ash + crude protein + lipid $\%+$ fibre) $] \mathrm{g} \mathrm{kg}^{-1}$.

${ }^{4}$ Calculated as: available $P=$ total $P$ - phytate $P$ (Sajjadi \& Carter 2004). and one pretreatment control (diet 8) with neither phytase pretreatment nor inorganic $\mathrm{P}$ supplement but with phytase added directly to feed ingredients. Diet 8 was prepared at a phytase dose of $1000 \mathrm{U} \mathrm{kg}^{-1}$ by dissolving phytase in distilled water before pelleting.

For diet preparation, dry ingredients were mixed in a Hobart-type mixer (Anoma Taiwan Machinery Co., Taiwan). Fish oil in the diets was included in the mixer prior to extrusion. Diets were pelleted (3 $\mathrm{mm}$ in diameter) with a laboratory extrusion system at $80{ }^{\circ} \mathrm{C}$. Pelleted diets were air dried, crumbled into 1-2 $\mathrm{mm}$ in diameter with a grinder, and stored in sealed plastic bags at $4{ }^{\circ} \mathrm{C}$ until use.

\section{Growth trial}

A growth trial was conducted in 24 in-door recirculating circular cement tanks ( $1 \mathrm{~m}$ in both depth and diameter) at AIT from 20 March to 21 May 2006, to assess effects of experimental diets pretreated with phytase on the growth performance of Nile tilapia. Water flow rate was fixed at $1 \mathrm{~L} \mathrm{~min}^{-1}$ to maintain a water depth of $0.7 \mathrm{~m}$ in all experimental tanks. Eight experimental diets were assigned randomly to experimental tanks with three replicates each. Sex-reversed all-male Nile tilapia fingerlings of $0.7-0.8 \mathrm{~g}$ in size were stocked at 30 fish $\operatorname{tank}^{-1}$, and fed with the experimental diets to apparent satiation twice daily at 09:00-10:00 and 16:00-17:00 h. All experimental fish were purchased from the hatchery of AIT. Samples of diets and six fish per tank were collected at the beginning for analyses of whole body composition. Uneaten pellets and faeces in all tanks were removed by siphon everyday. Tank water samples, taken weekly at 09:00 h, were analysed for total alkalinity, total ammonia nitrogen, total Kjeldahl nitrogen and total P, using standard methods [APHA (American Public Health Association), American Water Works Association and Water Pollution Control Federation 1985]. Temperature, dissolved oxygen and $\mathrm{pH}$ (at $20 \mathrm{~cm}$ below the water surface) were measured in situ according to the same schedule. Water quality parameters in the experimental tanks were maintained within acceptable levels for tilapia (Plumb 1999) by using the physical and biological filters in the recycling system. Feed intake was calculated by subtracting the number of uneaten from supplied pellets. Feed intake was monitored in this way everyday throughout the experiment. At the end of the growth trial, all fish were deprived of food for 1 day before counting and weighing. Six fish per tank were collected for analyses of whole body composition. Then feed conversion ratio (FCR), specific growth rate (SGR) and protein efficiency ratio (PER) were calculated. 
Table 2 Experimental diets for Nile tilapia juveniles

\begin{tabular}{|c|c|c|c|c|c|c|c|c|}
\hline & $\begin{array}{l}\text { Phytase } \\
\text { control } \\
\text { (diet 1) }\end{array}$ & $\begin{array}{l}\text { Inorganic-P } \\
\text { control } \\
\text { (diet 2) }\end{array}$ & $\begin{array}{l}100 \% \text { MCP } \\
\text { supplement } \\
\text { (diet } 3 \text { ) }\end{array}$ & $\begin{array}{l}75 \% \text { MCP } \\
\text { supplement } \\
\text { (diet 4) }\end{array}$ & $\begin{array}{l}50 \% \mathrm{MCP} \\
\text { supplement } \\
\text { (diet 5) }\end{array}$ & $\begin{array}{l}25 \% \mathrm{MCP} \\
\text { supplement } \\
\text { (diet 6) }\end{array}$ & $\begin{array}{l}0 \% \text { MCP } \\
\text { supplement } \\
\text { (diet 7) }\end{array}$ & $\begin{array}{l}\text { Pretreatment } \\
\text { control } \\
\text { (diet 8) }\end{array}$ \\
\hline \multicolumn{9}{|c|}{ Ingredients (g kg ${ }^{-1}$, as-fed basis) } \\
\hline Soybean meal & 536.5 & 536.5 & 536.5 & 536.5 & 536.5 & 536.5 & 536.5 & 536.5 \\
\hline Corn gluten meal & 200.0 & 200.0 & 200.0 & 200.0 & 200.0 & 200.0 & 200.0 & 200.0 \\
\hline Wheat & 100.0 & 100.0 & 100.0 & 100.0 & 100.0 & 100.0 & 100.0 & 100.0 \\
\hline Cassava & 103.5 & 78.5 & 78.5 & 84.75 & 91.0 & 97.25 & 103.5 & 103.5 \\
\hline Fish oil & 35 & 35 & 35 & 35 & 35 & 35 & 35 & 35 \\
\hline Soy lecithin & 10 & 10 & 10 & 10 & 10 & 10 & 10 & 10 \\
\hline Mineral premix ${ }^{1}$ & 10 & 10 & 10 & 10 & 10 & 10 & 10 & 10 \\
\hline Vitamin premix ${ }^{2}$ & 5 & 5 & 5 & 5 & 5 & 5 & 5 & 5 \\
\hline $\mathrm{Ca}\left(\mathrm{H}_{2} \mathrm{PO}_{4}\right)_{2}$ & 0 & 25.0 & 25.0 & 18.75 & 12.5 & 6.25 & 0 & 0 \\
\hline Total & 1000 & 1000 & 1000 & 1000 & 1000 & 1000 & 1000 & 1000 \\
\hline Phytase $^{3}\left(\mathrm{U} \mathrm{kg}^{-1}\right)$ & 0 & 0 & $1000^{4}$ & $1000^{4}$ & $1000^{4}$ & $1000^{4}$ & $1000^{4}$ & $1000^{5}$ \\
\hline \multicolumn{9}{|c|}{ Proximate composition ( $\mathrm{g} \mathrm{kg}^{-1}$, dry matter basis) } \\
\hline Dry matter & 890.9 & 893.3 & 891.2 & 892.7 & 892.1 & 891.5 & 890.1 & 891.9 \\
\hline Crude protein & 363.8 & 363.1 & 364.2 & 364.7 & 363.9 & 363.5 & 364.3 & 363.0 \\
\hline Crude fat & 57.1 & 57.9 & 56.8 & 57.5 & 56.9 & 57.7 & 57.0 & 56.6 \\
\hline Ash & 51.0 & 73.2 & 75.9 & 69.7 & 63.4 & 57.2 & 51.6 & 52.2 \\
\hline Calcium & 2.0 & 6.2 & 6.1 & 5.2 & 4.1 & 3.1 & 1.9 & 2.0 \\
\hline Total-P & 4.5 & 11.1 & 11.1 & 9.6 & 7.8 & 6.2 & 4.5 & 4.4 \\
\hline Phytate-P & 3.0 & 3.3 & 0.9 & 0.8 & 0.6 & 1.0 & 0.7 & 2.0 \\
\hline Available-P & 1.5 & 7.8 & 10.2 & 8.8 & 7.2 & 5.2 & 3.8 & 2.4 \\
\hline
\end{tabular}

MCP, mono calcium phosphate; $P$, phosphorus.

${ }^{1}$ Mineral premix (per kg of diet): the same as Table 1 stated.

${ }^{2}$ Vitamin premix Roche 2118 (Hoffman-La Roche, Inc., Nutley, NJ, USA) (per kg of diet): the same as Table 1 stated.

${ }^{3}$ Phytase: provided by Sichuan Habio Bioengineering Co. Ltd., Chengdu, Sichuan, China. Enzyme activity: $5000 \mathrm{U} \mathrm{g}^{-1}$

${ }^{4}$ Plant ingredients were pretreated with phytase at $1000 \mathrm{U} \mathrm{kg}^{-1}$ before mixed with other feed ingredients.

${ }^{5}$ Phytase mixed directly with other ingredients without pretreatment before pelleted

Nutrient retention efficiency of phosphorus was calculated as:

Phosphorus retention $\%=\frac{100 \times(\mathrm{FBW} \times \mathrm{Nf}-\mathrm{IBW} \times \mathrm{Ni})}{(\text { feed intake } \times \mathrm{N} \text { diet })}$

where FBW is the final body weight and IBW is the initial body weight of fish, $\mathrm{N}$ is the concentration of nutrient $(\mathrm{P})$ in the fish at the start $(\mathrm{Ni})$ and end $(\mathrm{Nf})$ of the experiment (Storebakken et al. 1998).

Phosphorus load was calculated as (Vielma et al. 2002):

$$
\mathrm{P} \text { load }\left(\mathrm{g} \mathrm{P} \mathrm{kg}^{-1}\right)=\frac{(\mathrm{P} \text { fed, } \mathrm{g})-(\mathrm{P} \text { deposited, } \mathrm{g})}{(\text { Weight gain, } \mathrm{kg})}
$$

\section{Digestibility trial}

A digestibility trial was conducted after the termination of the growth trial in twenty-four $80-\mathrm{L}$ fibreglass tanks. Ten sex-reversed all-male Nile tilapia fingerlings of approximately $25 \mathrm{~g}$ in size were stocked in each fibreglass tank with an air stone. Experimental diets used in the growth trial were the same as those used in the digestibility trial with three replicates for each diet. The digestibility trial was conducted from 25 May to 10
June 2006 for 15 days. Fish were fed commercial feed during a 3-day acclimation period, after which the experimental diets were fed twice daily (09:00-10:00 and 16:00-17:00 h) at a rate of $3 \%$ body weight per day for 5 days for dietary adaptation. Starting from day 6 , faeces were collected twice a day for 10 days and pooled by each treatment tank. One hour after feeding, water was completely changed in all tanks to remove uneaten feed, and faeces were collected using complete membrane from the tank bottom $3 \mathrm{~h}$ after each feeding according to the method described by Lim et al. (2004). Daily collected faeces were air-dried at $55^{\circ} \mathrm{C}$. Samples of faeces were kept in a desiccator for analyses of crude protein and total $\mathrm{P}$ using standard methods [AOAC (Association of Official Analytical Chemists) 2000]. Apparent digestibility coefficients (ADC) of crude protein and $\mathrm{P}$ for eight diets were determined by the hydrolysis resistant organic matter (HROM) method (Buddington 1980). ADC was calculated according to:

$$
\begin{aligned}
\text { ADC } \%= & 100-(100)\left[\frac{\% \text { HROM in feed }}{\% \text { HROM in faeces }}\right. \\
& \left.\times \frac{\% \text { Nutrient in faeces }}{\% \text { Nutrient in feed }}\right]
\end{aligned}
$$




\section{Chemical analysis}

The chemical analyses of diets, fish whole-body and faeces were performed according to standard methods [AOAC (Association of Official Analytical Chemists) 2000]: dry matter (dried at $105^{\circ} \mathrm{C}$ ), crude protein (Kjeldahl method), crude lipid (ether extract according to soxhlet method) and ash (combusted at $550{ }^{\circ} \mathrm{C}$ for $6 \mathrm{~h}$ ). The measurement of crude fibre (CF) involves extraction of a ground feed sample with diethyl ether followed by sequential boiling in dilute acid and dilute base. The residue is then burned in a $500-600{ }^{\circ} \mathrm{C}$ muffle furnace. $\mathrm{CF}$ $\%$ is calculated from the difference in weight of the sample before and after burning [AOAC (Association of Official Analytical Chemists) 2000]. Calcium was analysed using atomic absorption phase spectrophotometer (Spectra-55, Varian) after acid digestion. Phosphorus content in fish whole body was determined in three replicates using the vanadiummolybdate method described by AOAC (Association of Official Analytical Chemists) (2000). Absorbance of the vanadomolybdo phosphorus complex was measured at $430 \mathrm{~nm}$ using a UV-VIS spectrophotometer (Specord S100, Carl Zeiss, CA, USA). Phytate $\mathrm{P}$ in feed ingredients was analysed by anionexchange method (Latta \& Eskin 1980; Harland \& Oberleas 1986) using a 100-200 mesh AG1-X4 chloride anion exchange column (Bio-Rad Laboratory, Hercules, California, USA). Phytate is extracted from feed ingredients using diluted $\mathrm{HCl}$. Extraction is then placed on an ion-exchange column. Phytate is eluted with $0.7 \mathrm{M} \mathrm{NaCl}$ solution and wet-digested with mixture of concentrated $\mathrm{HNO}_{3} / \mathrm{H}_{2} \mathrm{SO}_{4}$ to release phytate $\mathrm{P}$, which is measured colorimetrically at $640 \mathrm{~nm}$ using a UV-VIS spectrophotometer (Specord S100, Carl Zeiss) (Harland \& Oberleas 1986). Available $\mathrm{P}$ was calculated by deducting phytate P from total P (Sajjadi \& Carter 2004). Phytase efficacy was calculated as follows:

$$
\text { Efficacy }=100 \times \frac{\text { initial phytate } \mathrm{P}-\text { final phytate } \mathrm{P}}{\text { initial phytate } \mathrm{P}}
$$

\section{Statistical analysis}

Data were analysed statistically using ANOvA and regression (Steele \& Torrie 1980) with sPss (version 11.5) statistical software package (SPSS Inc., Chicago, IL, USA). ANOvA for percentage data was performed on arcsine transformed data, while the percentage data were presented in the original scale. Treatment means were compared using Least Significant Difference and differences among treatments were considered significant at an alpha level of 0.05 . Mean values were given with \pm SD.

\section{Results}

\section{Pretreatment of plant ingredients}

After the pretreatment, phytate $\mathrm{P}$ contents of both soybean meal and mixed plant meal decreased, while the available $\mathrm{P}$ contents increased for all levels of phytase doses including the controls (Tables $3 \& 4$ ).

Final available $\mathrm{P}$ and efficacy of converting phytate $\mathrm{P}$ to available $\mathrm{P}$ increased significantly with increasing doses of phytase for both soybean meal (Fig. 1) and mixed plant meal (Fig. 2). Based on two figures, curve equations for soybean meal and mixed plant meal can be written as: $Y=11.1907$ $X^{0.2841} \quad\left(R^{2}=0.9078, \quad n=15, \quad P<0.05\right) ; \quad Y=29.7048$ $X^{0.14567}\left(R^{2}=0.9158, n=18, P<0.05\right)$, where $Y$ is the efficacy of phytase indicating how much phytate $\mathrm{P}$ in the plant materials can be converted to available $\mathrm{P} ; X$ is the dose of phytase used for pretreatment. According to the inflexion calculation of curves (Lanari et al. 1998; Jiang et al. 2006), the dose of $1000 \mathrm{U} \mathrm{kg}^{-1}$ was determined as the most cost effective dose.

\section{Growth performance}

Pretreatment of plant ingredients with phytase and P supplementation both had significantly positive effects on growth performance of Nile tilapia. Survivals were all higher than $90 \%$, ranging from $90.0 \%$ to $96.7 \%$ among treatments (Table 5). Growth performance in terms of final mean weight, weight gain and daily weight gain was best in the treatments supplemented with $12.5,18.75$ and $25 \mathrm{~g} \mathrm{~kg}^{-1}$ $\mathrm{MCP}$ and the inorganic $\mathrm{P}$ control, intermediate in the treatments supplemented with MCP at 6.25 and $0 \mathrm{~g} \mathrm{~kg}^{-1}$, and poorest in the pretreatment control and the phytase control $(P<0.05)$. SGR showed similar patterns of differences among treatments to other growth performance parameters, with the highest SGR in the treatment with MCP supplement at $12.5 \mathrm{~g} \mathrm{~kg}^{-1}$. Fish fed diets untreated with phytase showed poorer FCR, while FCR ranging from 1.10 to 1.85 was best in the treatments with MCP supplement at 12.5 and $25 \mathrm{~g} \mathrm{~kg}^{-1}$ as well as the inorganic $\mathrm{P}$ control $(P<0.05)$, which were not significantly different from the treatment with MCP supplement at $18.75 \mathrm{~g} \mathrm{~kg}^{-1}(P>0.05)$, but were significantly better than all other treatments $(P<0.05)$. PER ranged from 1.49 in the phytase control to 2.66 in the diet supplemented with MCP at $12.5 \mathrm{~g} \mathrm{~kg}^{-1}$.

The addition of phytase and inorganic $\mathrm{P}$ to the basal diet significantly increased the contents of ash, $\mathrm{P}$ and crude protein in the whole body of Nile tilapia (Table 6), while dry 


\begin{tabular}{|c|c|c|c|c|c|}
\hline \multirow[b]{2}{*}{ Phytase $\left(\mathrm{U} \mathrm{kg}{ }^{-1}\right)$} & \multirow[b]{2}{*}{ Total $\mathrm{P}\left(\mathrm{g} \mathrm{kg}^{-1}\right)$} & \multicolumn{2}{|c|}{ Phytate $P\left(\mathrm{~g} \mathrm{~kg}^{-1}\right)$} & \multicolumn{2}{|c|}{ Available $P^{2}\left(\mathrm{~g} \mathrm{~kg}^{-1}\right)$} \\
\hline & & Initial & Final & Initial & Final \\
\hline 0 & $6.40 \pm 0.03$ & $4.30 \pm 0.02$ & $3.56 \pm 0.005^{a}$ & $2.10 \pm 0.05$ & $2.82 \pm 0.014^{a}$ \\
\hline 500 & $6.40 \pm 0.03$ & $4.30 \pm 0.02$ & $1.44 \pm 0.005^{\mathrm{b}}$ & $2.10 \pm 0.05$ & $4.96 \pm 0.012^{\mathrm{b}}$ \\
\hline 750 & $6.40 \pm 0.03$ & $4.30 \pm 0.02$ & $1.27 \pm 0.012^{c}$ & $2.10 \pm 0.05$ & $5.13 \pm 0.008^{c d}$ \\
\hline 1000 & $6.40 \pm 0.03$ & $4.30 \pm 0.02$ & $0.78 \pm 0.005^{d}$ & $2.10 \pm 0.05$ & $5.62 \pm 0.011^{\mathrm{de}}$ \\
\hline 1500 & $6.40 \pm 0.03$ & $4.30 \pm 0.02$ & $0.47 \pm 0.005^{\mathrm{e}}$ & $2.10 \pm 0.05$ & $5.93 \pm 0.017^{e}$ \\
\hline
\end{tabular}

${ }^{1}$ Values are means \pm SD $(n=3)$. Values in the same column with different superscript letters are significantly different $(P<0.05)$.

${ }^{2}$ Calculated as: available phosphorus $(P)=$ total $P$ - phytate $P$ (Sajjadi \& Carter 2004).

\begin{tabular}{|c|c|c|c|c|c|}
\hline \multirow{2}{*}{$\begin{array}{l}\text { Phytase } \\
\left(\mathrm{U} \mathrm{kg}^{-1}\right)\end{array}$} & \multirow{2}{*}{$\begin{array}{l}\text { Total P } \\
\left(\mathrm{g} \mathrm{kg}^{-1}\right)\end{array}$} & \multicolumn{2}{|c|}{ Phytate $P\left(\mathrm{~g} \mathrm{~kg}^{-1}\right)$} & \multicolumn{2}{|c|}{ Available $\mathrm{P}^{2}\left(\mathrm{~g} \mathrm{~kg}^{-1}\right)$} \\
\hline & & Initial & Final & Initial & Final \\
\hline 0 & $4.50 \pm 0.002$ & $3.00 \pm 0.004$ & $2.26 \pm 0.002^{a}$ & $1.50 \pm 0.006$ & $2.24 \pm 0.002^{a}$ \\
\hline 500 & $4.50 \pm 0.002$ & $3.00 \pm 0.004$ & $0.73 \pm 0.007^{b}$ & $1.50 \pm 0.006$ & $3.77 \pm 0.007^{b}$ \\
\hline 750 & $4.50 \pm 0.002$ & $3.00 \pm 0.004$ & $0.63 \pm 0.009^{b}$ & $1.50 \pm 0.006$ & $3.87 \pm 0.009^{b}$ \\
\hline 1000 & $4.50 \pm 0.002$ & $3.00 \pm 0.004$ & $0.49 \pm 0.010^{c}$ & $1.50 \pm 0.006$ & $4.01 \pm 0.010^{c}$ \\
\hline 1500 & $4.50 \pm 0.002$ & $3.00 \pm 0.004$ & $0.36 \pm 0.005^{d}$ & $1.50 \pm 0.006$ & $4.14 \pm 0.005^{d}$ \\
\hline 3000 & $4.50 \pm 0.002$ & $3.00 \pm 0.004$ & $0.14 \pm 0.003^{\mathrm{e}}$ & $1.50 \pm 0.006$ & $4.36 \pm 0.003^{\mathrm{e}}$ \\
\hline
\end{tabular}

${ }^{1}$ Values are mean $\pm \mathrm{SD}(n=3)$. Values in the same column with different superscript letters are significantly different $(P<0.05)$.

${ }^{2}$ Calculated as: available phosphorus $(P)=$ total $P$ - phytate $P$ (Sajjadi \& Carter 2004).
Table 3 Changes of phytate $\mathrm{P}$ and available $\mathrm{P}$ after the pretreatment of soybean meal using phytase at different doses $^{1}$

Table 4 Changes of phytate $\mathrm{P}$ and available $\mathrm{P}$ after the pretreatment of the mixed plant meal using phytase at different doses ${ }^{1}$

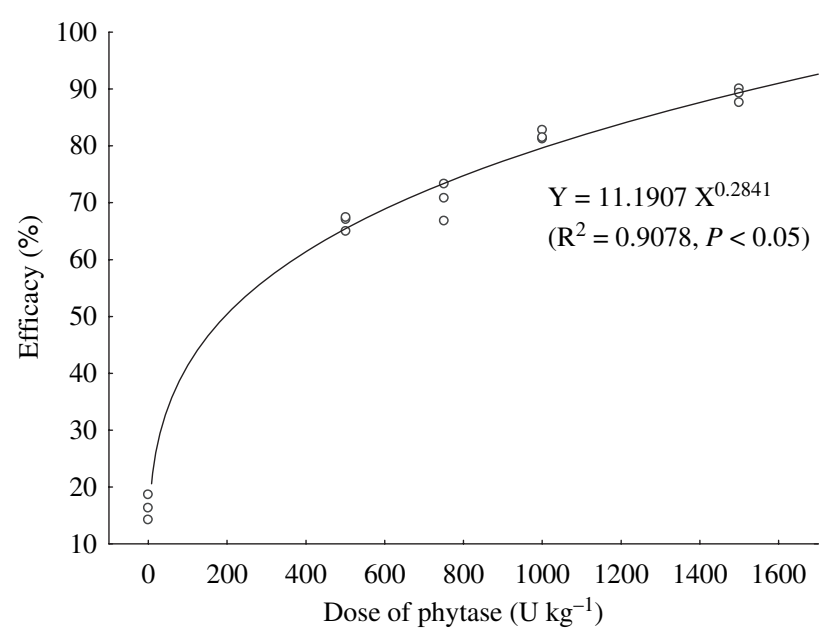

Figure 1 Efficacy of converting phytate phosphorus $(\mathrm{P})$ to available $\mathrm{P}$ by the pretreatment of soybean meal using phytase at different doses.

matter and lipid contents decreased significantly $(P<0.05)$. Compared with the phytase control and pretreatment control, significantly higher levels of $\mathrm{P}$ contents in tilapia carcass ranging from 1.68 to $1.83 \mathrm{~g} \mathrm{~kg}^{-1}$ were found in the inorganic $\mathrm{P}$ control (diet 2), $25 \mathrm{~g} \mathrm{~kg}^{-1}$ MCP supplement (diet 3), $18.75 \mathrm{~g} \mathrm{~kg}^{-1} \mathrm{MCP}$ supplement (diet 4), $12.5 \mathrm{~g} \mathrm{~kg}^{-1} \mathrm{MCP}$ supplement (diet 5), $6.25 \mathrm{~g} \mathrm{~kg}^{-1}$ MCP supplement (diet 6)

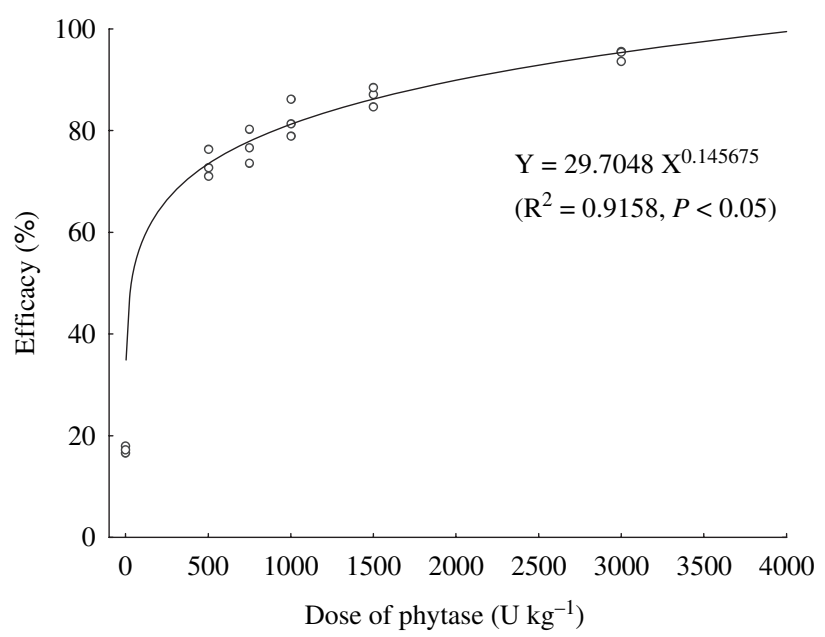

Figure 2 Efficacy of converting phytate phosphorus (P) to available $\mathrm{P}$ by the pretreatment of the mixed plant meal using phytase at different doses.

and $0 \mathrm{~g} \mathrm{~kg}^{-1}$ MCP supplement (diet 7) $(P<0.05)$. There were no significant differences in $\mathrm{P}$ contents for whole body of Nile tilapia between the inorganic P control (diet 2), $25 \mathrm{~g} \mathrm{~kg}^{-1}$ MCP supplement (diet 3), $18.75 \mathrm{~g} \mathrm{~kg}^{-1}$ MCP supplement (diet 4) and $12.5 \mathrm{~g} \mathrm{~kg}^{-1} \mathrm{MCP}$ supplement (diet 5) $(P>0.05)$. $\mathrm{P}$ deficiency of Nile tilapia in the phytase control (diet 1), $0 \mathrm{~g} \mathrm{~kg}^{-1} \mathrm{MCP}$ supplement (diet 7) and pretreatment 
Table 5 Growth performance of Nile tilapia juveniles fed the experimental diets for 60 days

\begin{tabular}{|c|c|c|c|c|c|c|c|c|c|}
\hline \multirow[b]{2}{*}{ Parameter } & \multirow[b]{2}{*}{ Unit } & \multicolumn{8}{|c|}{ Experimental diets } \\
\hline & & $\begin{array}{l}\text { Phytase } \\
\text { control } \\
\text { (diet 1) }\end{array}$ & $\begin{array}{l}\text { Inorganic P } \\
\text { control } \\
\text { (diet } 2 \text { ) }\end{array}$ & $\begin{array}{l}100 \% \text { MCP } \\
\text { supplement } \\
\text { (diet } 3 \text { ) }\end{array}$ & $\begin{array}{l}75 \% \text { MCP } \\
\text { supplement } \\
\text { (diet 4) }\end{array}$ & $\begin{array}{l}50 \% \text { MCP } \\
\text { supplement } \\
\text { (diet 5) }\end{array}$ & $\begin{array}{l}25 \% \mathrm{MCP} \\
\text { supplement } \\
\text { (diet 6) }\end{array}$ & $\begin{array}{l}0 \% \mathrm{MCP} \\
\text { supplement } \\
\text { (diet } 7 \text { ) }\end{array}$ & $\begin{array}{l}\text { Pretreatment } \\
\text { control } \\
\text { (diet 8) }\end{array}$ \\
\hline Init & g & 09 & $0.74 \pm 0.09$ & 0.73 & 0.74 & $0.70 \pm$ & 0.77 & 0.80 & 0.7 \\
\hline Final mean weight & g & $19.1 \pm 0.60^{\mathrm{e}}$ & $34.6 \pm 0.76^{a}$ & $34.9 \pm 1.23^{a}$ & $34.6 \pm 0.56^{a}$ & $35.8 \pm 1.21^{\mathrm{a}}$ & $30.8 \pm 0.74^{b}$ & $26.8 \pm 0.45^{c}$ & $23.0 \pm 1.07^{\mathrm{d}}$ \\
\hline Survival & $\%$ & $95.0 \pm 2.3^{\mathrm{a}}$ & $96.6 \pm 0.0^{\mathrm{a}}$ & $91.6 \pm 2.3^{c}$ & $93.3 \pm 4.2^{b}$ & $91.6 \pm 2.3^{c}$ & $93.3 \pm 4.2^{b}$ & $90.0 \pm 0.0^{c}$ & $96.6 \pm 0.0^{\mathrm{a}}$ \\
\hline $\mathrm{FCR}^{1}$ & $\%$ day $^{-1}$ & $1.85 \pm 0.03^{\mathrm{e}}$ & $1.12 \pm 0.07^{\mathrm{a}}$ & $1.14 \pm 0.00^{\mathrm{a}}$ & $1.16 \pm 0.01^{\mathrm{ab}}$ & $1.10 \pm 0.06^{a}$ & $1.24 \pm 0.04^{b}$ & $1.35 \pm 0.02^{c}$ & $1.64 \pm 0.04^{d}$ \\
\hline$S G R^{2}$ & & $5.45 \pm 0.16^{\mathrm{e}}$ & $6.43 \pm 0.25^{\mathrm{ab}}$ & $6.44 \pm 0.06^{\mathrm{ab}}$ & $6.43 \pm 0.18^{\mathrm{ab}}$ & $6.56 \pm 0.06^{a}$ & $6.16 \pm 0.14^{b c}$ & $5.85 \pm 0.03^{c d}$ & $5.75 \pm 0.14^{\mathrm{de}}$ \\
\hline $\mathrm{PER}^{3}$ & & $1.49 \pm 0.02^{\mathrm{e}}$ & $2.59 \pm 0.04^{a}$ & $2.54 \pm 0.08^{a}$ & $2.61 \pm 0.04^{a}$ & $2.66 \pm 0.08^{\mathrm{a}}$ & $2.36 \pm 0.06^{b}$ & $2.16 \pm 0.04^{c}$ & $1.68 \pm 0.04^{d}$ \\
\hline
\end{tabular}

$\mathrm{MCP}$, mono calcium phosphate; $\mathrm{P}$, phosphorus.

${ }^{1}$ Feed conversion ratio $(F C R)=$ dry feed weight given $(g) /$ wet fish weight gained $(g)$.

${ }^{2}$ Specific growth rate $(\mathrm{SGR})\left(\%\right.$ day $\left.^{-1}\right)=100 \times[$ (In final mean weight - In initial mean weight $) /$ days of the experiment $]$.

${ }^{3}$ Protein efficiency ratio PER $=$ fish weight gained $(g) /$ protein given $(g)$.

Values are mean $\pm \mathrm{SD}(n=3)$, values with different superscript letters in the same row are significantly different $(P<0.05)$.

Table 6 Whole-body chemical composition ( $\mathrm{g} \mathrm{kg}^{-1}$, dry matter basis) of Nile tilapia juveniles fed the experimental diets for 60 days

\begin{tabular}{|c|c|c|c|c|c|c|c|c|}
\hline \multirow[b]{2}{*}{ Parameter } & \multicolumn{8}{|c|}{ Experimental diets } \\
\hline & $\begin{array}{l}\text { Phytase } \\
\text { control } \\
\text { (diet 1) }\end{array}$ & $\begin{array}{l}\text { Inorganic } \\
\text { P control } \\
\text { (diet 2) }\end{array}$ & $\begin{array}{l}100 \% \mathrm{MCP} \\
\text { supplement } \\
\text { (diet } 3 \text { ) }\end{array}$ & $\begin{array}{l}75 \% \text { MCP } \\
\text { supplement } \\
\text { (diet 4) }\end{array}$ & $\begin{array}{l}50 \% \mathrm{MCP} \\
\text { supplement } \\
\text { (diet } 5 \text { ) }\end{array}$ & $\begin{array}{l}25 \% \mathrm{MCP} \\
\text { supplement } \\
\text { (diet 6) }\end{array}$ & $\begin{array}{l}0 \% \mathrm{MCP} \\
\text { supplement } \\
\text { (diet } 7 \text { ) }\end{array}$ & $\begin{array}{l}\text { Pretreatment } \\
\text { control } \\
\text { (diet 8) }\end{array}$ \\
\hline Dry matter & $259.3 \pm 0.4^{a}$ & $231.0 \pm 0.3^{\mathrm{e}}$ & $230.5 \pm 0.1^{\mathrm{e}}$ & $230.9 \pm 0.6^{\mathrm{e}}$ & $231.3 \pm 0.4^{\mathrm{e}}$ & $232.9 \pm 1.0^{d}$ & $237.8 \pm 1.1^{c}$ & $253.6 \pm 0.4^{b}$ \\
\hline Ash & $88.0 \pm 0.1^{d}$ & $106.1 \pm 0.3^{a}$ & $106.1 \pm 1.0^{a}$ & $105.5 \pm 0.7^{a}$ & $105.3 \pm 0.4^{\mathrm{ab}}$ & $104.2 \pm 0.6^{\mathrm{b}}$ & $96.5 \pm 0.7^{c}$ & $89.0 \pm 0.1^{d}$ \\
\hline Lipid & $188.4 \pm 0.1^{\mathrm{a}}$ & $133.8 \pm 0.3^{c d}$ & $132.9 \pm 0.7^{d}$ & $134.0 \pm 0.6^{\mathrm{cd}}$ & $133.1 \pm 0.4^{\mathrm{d}}$ & $134.8 \pm 2.4^{\mathrm{cd}}$ & $135.9 \pm 1.1^{c}$ & $175.3 \pm 0.9^{\mathrm{b}}$ \\
\hline Crude protein & $507.6 \pm 6.5^{c}$ & $553.4 \pm 4.0^{\mathrm{a}}$ & $549.7 \pm 3.9^{a}$ & $548.1 \pm 2.7^{a}$ & $550.0 \pm 3.4^{\mathrm{a}}$ & $531.4 \pm 6.0^{\mathrm{b}}$ & $527.2 \pm 6.3^{b}$ & $513.7 \pm 9.7^{c}$ \\
\hline Phosphorous & $13.3 \pm 0.5^{\mathrm{e}}$ & $18.3 \pm 0.4^{\mathrm{a}}$ & $18.6 \pm 0.5^{a}$ & $17.9 \pm 0.4^{\mathrm{a}}$ & $18.1 \pm 0.5^{a}$ & $17.4 \pm 0.2^{\mathrm{b}}$ & $16.8 \pm 0.3^{c}$ & $14.3 \pm 0.3^{d}$ \\
\hline
\end{tabular}

$\mathrm{MCP}$, mono calcium phosphate; $\mathrm{P}$, phosphorus.

Values are means \pm SD $(n=3)$; values with different superscript letters in the same rows are significantly different $(P<0.05)$.

control (diet 8) was observed by abnormal head, curved vertebra and loose scale during the trial period. The lowest levels of ash, $\mathrm{P}$ and crude protein contents and highest contents of dry matter and lipid in the whole body of Nile tilapia were all found in the phytase control (diet 1).

\section{Phosphorus retention efficiency and load}

Dietary interaction effects of phytase were observed for phosphorus retention efficiency and phosphorus load (Table 7). $P$ retention efficiency was significantly higher for diet 5, 6 and 7, intermediate for 2, 3 and 4 and significantly lower for 1 and $8(P<0.05)$. $\mathrm{P}$ load was significantly higher for diet 1 and 8 , intermediate for 2, 3 and 4 and significantly lower for 5, 6 and $7(P<0.05)$.

\section{Apparent digestibility}

Apparent digestibility coefficient of phosphorus (ADCp) were enhanced by the phytase pretreatment, however, there were no significant differences in apparent digestibility coefficient of crude protein (ADCcp) among all treatments. $\mathrm{ADC}_{\mathrm{CP}}$ of the eight experimental diets ranged from $83.10 \%$ to $85.27 \%$ did not significantly differ each other $(P>0.05$, Table 8). However, phytase pretreatment significantly increased $\mathrm{ADC}_{\mathrm{P}}$ of the experimental diets $(P<0.05) . \mathrm{ADC}_{\mathrm{P}}$ values in the diets supplemented with $12.5 \mathrm{~g} \mathrm{~kg}^{-1}$ or less MCP (diets 5, 6 and 7) were significantly higher than those in all other diets including the diets supplemented with more than $12.5 \mathrm{~g} \mathrm{~kg}^{-1} \mathrm{MCP}$ as well as the three control diets $(P<0.05)$.

\section{Discussion}

Pretreatment of plant ingredients using microbial phytase significantly increased available $P$ content in feed, indicating that the indigestible phytate $\mathrm{P}$ was successfully converted to available $\mathrm{P}$ by phytase in the present study. The relationships between the amount of available $P$ released from phytate $P$ and the doses of phytase administered can be used to predict 


\begin{tabular}{llll}
\hline Diet & Treatment & P retention (\%) & P load $\left(\mathrm{g} \mathrm{kg}^{-1}\right)$ \\
\hline Phytase control (diet 1) & None & $28.56 \pm 1.17^{\mathrm{c}}$ & $6.39 \pm 0.17^{\mathrm{a}}$ \\
Inorganic P control (diet 2) & $+25 \mathrm{~g} \mathrm{MCP} \mathrm{kg}{ }^{-1}$ & $49.67 \pm 1.11^{\mathrm{b}}$ & $4.64 \pm 0.55^{\mathrm{b}}$ \\
$100 \%$ MCP supplement (diet 3) & Phytase $+25 \mathrm{~g} \mathrm{MCP} \mathrm{kg}^{-1}$ & $51.75 \pm 1.02^{\mathrm{b}}$ & $4.32 \pm 0.05^{\mathrm{b}}$ \\
$75 \% \mathrm{MCP}$ supplement (diet 4) & Phytase $+18.75 \mathrm{~g} \mathrm{MCP} \mathrm{kg}^{-1}$ & $52.48 \pm 2.33^{\mathrm{b}}$ & $4.06 \pm 0.34^{\mathrm{b}}$ \\
$50 \%$ MCP supplement (diet 5) & Phytase + 12.5 g MCP kg & $59.84 \pm 1.34^{\mathrm{a}}$ & $3.49 \pm 0.02^{\mathrm{c}}$ \\
$25 \%$ MCP supplement (diet 6) & Phytase + 6.25 g MCP kg & $59.69 \pm 2.01^{\mathrm{a}}$ & $3.73 \pm 0.05^{\mathrm{c}}$ \\
$0 \%$ MCP supplement (diet 7) & Phytase & $57.38 \pm 1.07^{\mathrm{a}}$ & $3.30 \pm 0.02^{\mathrm{c}}$ \\
Pretreatment control (diet 8) & Phytase added directly & $32.59 \pm 1.14^{\mathrm{c}}$ & $6.11 \pm 0.19^{\mathrm{a}}$ \\
\hline
\end{tabular}

$\mathrm{MCP}$, mono calcium phosphate; $\mathrm{P}$, phosphorus.

Data are means \pm SD $(n=3)$; values in the same column with different superscript letters are significantly different $(P<0.05)$.

\begin{tabular}{llll}
\hline Diet & Treatment & ADC $_{\mathrm{CP}}(\%)$ & $\mathrm{ADC}_{\mathrm{P}}(\%)$ \\
\hline Phytase control (diet 1) & None & $84.40 \pm 1.47$ & $28.23 \pm 1.15^{f}$ \\
Inorganic P control (diet 2) & $+25 \mathrm{~g} \mathrm{MCP} \mathrm{kg}^{-1}$ & $84.37 \pm 0.83$ & $52.37 \pm 2.31^{\mathrm{c}}$ \\
$100 \% \mathrm{MCP}$ supplement (diet 3) & Phytase $+25 \mathrm{~g} \mathrm{MCP} \mathrm{kg}^{-1}$ & $84.43 \pm 0.56$ & $47.10 \pm 0.65^{\mathrm{d}}$ \\
$75 \% \mathrm{MCP}$ supplement (diet 4) & Phytase $+18.75 \mathrm{~g} \mathrm{MCP} \mathrm{kg}^{-1}$ & $84.57 \pm 0.61$ & $55.33 \pm 1.68^{\mathrm{b}}$ \\
$50 \% \mathrm{MCP}$ supplement (diet 5) & Phytase $+12.5 \mathrm{~g} \mathrm{MCP} \mathrm{kg}^{\mathrm{b}}$ & $85.27 \pm 0.65$ & $69.03 \pm 2.00^{\mathrm{a}}$ \\
$25 \% \mathrm{MCP}$ supplement (diet 6) & Phytase $+6.25 \mathrm{~g} \mathrm{MCP} \mathrm{kg}$ & $83.63 \pm 0.47$ & $69.47 \pm 0.38^{\mathrm{a}}$ \\
$0 \% \mathrm{MCP}$ supplement (diet 7) & Phytase & $83.10 \pm 0.91$ & $67.83 \pm 1.84^{\mathrm{a}}$ \\
Pretreatment control (diet 8) & Phytase added directly & $83.40 \pm 1.17$ & $36.03 \pm 0.97^{\mathrm{e}}$ \\
\hline
\end{tabular}

MCP, mono calcium phosphate; $P$, phosphorus.

Values are means $\pm \mathrm{SD}(n=3)$; values in the same column with different superscript letters are significantly different $(P<0.05)$.

the amount of available $\mathrm{P}$ to be released and the amount of inorganic $\mathrm{P}$ that may need to be supplemented at different dosages of phytase. In the present study, the release rates of available $\mathrm{P}$ from phytate $\mathrm{P}$ in soybean meal were about $66 \%$ and $82 \%$ at phytase doses of 500 and $1000 \mathrm{U} \mathrm{kg}^{-1}$ respectively, which are similar to those achieved by $\mathrm{Yu} \&$ Wang (2000). Other studies have shown that soybean meal treated by phytase at $500 \mathrm{U} \mathrm{kg}^{-1}$ released about $20 \%$ of phytate $\mathrm{P}$ (Schäfer et al. 1995), which increased to about $40 \%$ when the dose of phytase increased to $1000 \mathrm{U} \mathrm{kg}^{-1}$ (Cain \& Garling 1995). In the present study, the release rates of available $P$ from phytate $\mathrm{P}$ were $16.73 \%$ for soybean meal and $24.67 \%$ for the mixed plant ingredients when no phytase was added in the controls, due probably to the effect of citrate acid on hydrolysis of phytate in plant ingredients during the incubation. Sugiura et al. (2001) found that citric acid could chelate minerals and prevent their precipitation, indicating that citric acid can convert phytate $\mathrm{P}$ to available $\mathrm{P}$ to some extent. Thus, the pretreatment method might be an effective alternative for fish to maximize phytase activity and overcome temperature limitation (Cain \& Garling 1995; Yoo et al. 2005).

The growth performance and FCR of Nile tilapia after the 60-day growth trial was improved significantly when the pretreated diets with phytase at $1000 \mathrm{U} \mathrm{kg}^{-1}$ were used,
Table $7 \mathrm{P}$ retention efficiency and $\mathrm{P}$ load of Nile tilapia fed test diets for 60 days

Table 8 Apparent digestibility coefficients of crude protein $\left(\mathrm{ADC}_{\mathrm{CP}}\right)$ and $\mathrm{P}$ $\left(\mathrm{ADC}_{\mathrm{P}}\right)$ for the experimental diets fed to Nile tilapia juveniles compared with the phytase control diet in the present study. Higher PER of fish fed the diets containing phytase-treated than untreated meal indicates that the phytase or heating of the meal during the phytase treatment process improved the nutritional quality of the mixed plant meal. Liebert \& Portz (2005) reported the optimal growth of Nile tilapia was achieved by phytase supplementation at 750-1250 $\mathrm{U} \mathrm{kg}^{-1}$ in plant-based diets. Growth improvement was also observed in rainbow trout fed phytase-supplemented diets (Rodehutscord \& Pfeffer 1995; Papatryphon et al. 1999), and salmon and rainbow trout fed the diets with phytase pretreated ingredients (Cain \& Garling 1995; Vielma et al. 2002). However, the inclusion of phytase did not improve the growth of rainbow trout fed diets containing canola protein concentrate (Forster et al. 1999) and juvenile Korean rockfish (Sebastes schlegeli) fed diets containing soybean meal (Yoo et al. 2005). The available $\mathrm{P}$ contents in the phytase control diet, the diets without MCP supplement and the pretreatment control diet were lower than the minimum $\mathrm{P}$ requirement of Nile tilapia $\left(5 \mathrm{~g} \mathrm{~kg}^{-1}\right)$, and caused poor fish growth. The available $\mathrm{P}$ content in the diet supplemented with $6.25 \mathrm{~g} \mathrm{~kg}^{-1} \mathrm{MCP}$ was $5.6 \mathrm{~g} \mathrm{~kg}^{-1}$, which was slightly higher than the minimum requirement, but still resulting in poor growth of Nile tilapia than the inorganic P control in the present study, probably because that juvenile fish have 
higher P requirements than large fish [NRC (National Research Council) 1993; Cain \& Garling 1995]. Diets supplemented with more than $12.5 \mathrm{~g} \mathrm{~kg}^{-1} \mathrm{MCP}$ and the inorganic $\mathrm{P}$ control diet that contained around $9 \mathrm{~g} \mathrm{~kg}^{-1}$ of available $\mathrm{P}$ gave tilapia better growth than other diets in the present study, in agreement with that reported by Watanabe et al. (1980). Vielma et al. (2002) found better growth and feed utilization efficiency by pretreatment could be attributed partially to more efficient phytic acid hydrolysis in comparison to top-spraying phytase. Forster et al. (1999) reported that phytase top-sprayed onto soy protein-based diets at doses of $0,500,1500$ or $4500 \mathrm{U} \mathrm{kg}^{-1}$ diet did not have effect on growth or feed utilization efficiency in rainbow trout. Similarly, $2000 \mathrm{U}$ phytase $\mathrm{kg}^{-1}$ mixed in the feed prior to pelleting did not enhance performance of sea bass (Dicentrarchus labrax) despite a clear increase in $\mathrm{P}$ digestibility (Oliva-Teles et al. 1998). Further studies should be conducted to compare the economic benefits between the pretreatment and top-spraying with phytase at industrial level.

Ash, crude protein and $\mathrm{P}$ contents in whole Nile tilapia fed the phytase pretreated diets (diet 3, 4, 5, 6 and 7) were significantly higher than those fed diets 1 and 8 , indicating that phytase pretreatment led to improvement in carcass quality and $\mathrm{P}$ retention. Among all the diets, diets 2, 3, 4 and 5 performed best in terms of the growth, nutrient utilization and inorganic P replacement level in the present study. Compared with diets 2, 3 and 4, diet 5 supplement the least inorganic $\mathrm{P}$, only $50 \%$ of the inorganic control (diet 2) and diet 3. And the cost of diet 5 is less than the other three diets. So diet 5 supplemented with phytase at $1000 \mathrm{U} \mathrm{kg}^{-1}$ and $12.5 \mathrm{~g} \mathrm{~kg}^{-1} \mathrm{MCP}$ is the best, indicating that phytase at $1000 \mathrm{U} \mathrm{kg}^{-1}$ is comparable with $12.5 \mathrm{~g}$ MCP $\mathrm{kg}^{-1}$ diet. Schäfer et al. (1995) suggested that diets mainly based on plant proteins such as soybean meal have high contents of phytic acid, and the supplementation of phytase at levels of either 500 or $1000 \mathrm{U} \mathrm{kg}^{-1}$ can replace $1.9 \mathrm{~g}$ P from MCP. Phytase also increased deposition of $\mathrm{P}$ in the whole fish body, indicating that $\mathrm{P}$ load to the environment was reduced. Therefore, using phytase in plant-based diets can reduce the need for inorganic $\mathrm{P}$ supplementation in diets, leading to the reductions of $\mathrm{P}$ discharged to the environment from fish farms. Besides, lipid and dry matter contents in the whole body increased when Nile tilapia fed the low available $\mathrm{P}$ diets (diets 1 and 8), which agreed with the results in carp (Onishi et al. 1981) and rainbow trout (Rodehutscord 1996). The enhanced lipid and dry matter contents were probably caused by the inhibition of the $\beta$-oxidation of fatty acids resulting from a deficiency of P (Schäfer et al. 1995).
Phosphorus retention efficiency was significantly higher in fish fed phytase-supplemented diets compared with phytase control in the present study, indicating that phytase could improve phosphorus utilization. The lower retention values in diets 2, 3 and 4 were because of their exceeding the phosphorus requirement, demonstrating improved phosphorus utilization at dietary phosphorus near to requirement. When dietary phosphorus concentration increases above the requirements, the retention efficacy decreases. Factors like FCR, ingredient digestibility and dietary phosphorus content affect phosphorus load (Vielma et al. 2002). Using phytase in plant based diets in comparison with phytase control reduced phosphorus load. Hence, the inclusion of phytase in the diets is effective for aquaculture waste management. In the present study, phosphorus utilization was higher in the fish fed either the phytase or MCP-phytase diets. But in combination of phytase and MCP diets, there was no further advantage when the $\mathrm{P}$ level is above $\mathrm{P}$ requirement of tilapia. Because of the positive effect of phytase, the $P$ retention in juvenile Nile tilapia was improved while the total P load to the environment was reduced. Similar results have also been reported in salmon (Cain \& Garling 1995) and rainbow trout (Lanari et al. 1998; Sugiura et al. 2001) fed soybean meal based diets.

The pretreatment of mixed plant ingredients using phytase at $1000 \mathrm{U} \mathrm{kg}^{-1}$ diet significantly improved ADCp in the present study, compared with the phytase control diet and pretreatment control diet. The ADCp was reported to be the highest when dietary $\mathrm{P}$ level reached the $\mathrm{P}$ requirement of cultured fish, then declined with increasing dietary $\mathrm{P}$ levels (Riche \& Brown 1996). In the present study, the dietary P level in the diet with MCP supplement at $25 \mathrm{~g} \mathrm{~kg}^{-1}$ (diet 3) was the highest among all diets, and even higher than the $\mathrm{P}$ requirement of juvenile Nile tilapia because of the release of available $\mathrm{P}$ from phytate $\mathrm{P}$. However, the ADCp in this diet was significantly lower than the diets with less MCP supplements (diets 4, 5, 6 and 7) as well as the $\mathrm{P}$ control $(P<0.05)$, but significantly higher than that in the phytase control. The results with respect to digestibility of diets with MCP supplement and phytase pretreatment may also probably because of the interaction between MCP and phytase. Sugiura et al. (2001) also observed that the ADCp reached $93 \%$ in rainbow trout fed with a phytase pretreated diet containing $4.21 \mathrm{~g} \mathrm{~kg}^{-1}$ of total P. However, when the total P level increased to $14.7 \mathrm{~g} \mathrm{~kg}^{-1}$, the ADCp in diet containing phytase of $1000 \mathrm{U} \mathrm{kg}^{-1}$ was only $62 \%$. No significant difference was observed in the ADCcp in the present study, and the result was consistent to those reported by other studies (Riche et al. 2001; Sajjadi \& Carter 2004; Yoo et al. 2005). However, Furuya et al. (2001) observed that phytase at 
500-1500 $\mathrm{U} \mathrm{kg}^{-1}$ improved $\mathrm{P}$ availability and crude protein digestibility in Nile tilapia. More research should focus on the apparent digestibility of crude protein and profiles of amino acids in tilapia fed phytase pretreated plant-based diets.

In conclusion, the results of the present study have indicated that the optimal dose of phytase for the pretreatment of plant ingredients is $1000 \mathrm{U} \mathrm{kg}^{-1}$, which can efficiently convert phytate $\mathrm{P}$ to available $\mathrm{P}$ and replace $12.5 \mathrm{~g} \mathrm{~kg}^{-1}$ of the inorganic $\mathrm{P}$ supplementation to the diets for Nile tilapia juveniles without affecting their growth performance, apparent digestibility coefficients of both crude protein and P. The addition of phytase in the diets of Nile tilapia juveniles can reduce the use of $\mathrm{MCP}$, enhance the utilization of $\mathrm{P}$ in plant ingredients, and thus minimize the $\mathrm{P}$ discharge to the environment.

\section{Acknowledgements}

This research is a component of the Aquaculture Collaborative Research Support Program (ACRSP), supported by the US Agency for International Development (USAID) Grant No. LAG-G-00-96-90015-00, and by contributions from the University of Michigan, USA, the Asian Institute of Technology (AIT), Thailand and the Huazhong Agricultural University (HAU), China. The authors wish to thank Sichuan Habio Bioengineering Co., Ltd., Chengdu, Sichuan, China, for providing phytase and other support. The authors also wish to thank the staff of Aquaculture Laboratory at AIT for their field and lab assistance, and $\mathrm{Mr}$ Yang Chengtai at HAU for his assistance in manuscript preparation. The ACRSP accession number is 1329. The opinions expressed herein are those of the authors and do not necessarily reflect the views of the US Agency for International Development.

\section{References}

AOAC (Association of Official Analytical Chemists) (2000) Official Methods of Analysis of the Association of Official Analytical Chemists, 19th edn. Association of Official Analytical Chemists, Arlington, VA.

APHA (American Public Health Association), American Water Works Association and Water Pollution Control Federation (1985) Standard Methods for the Examination of Water and Wastewater, 15th edn. American Public Health Association, Washington, DC, $1134 \mathrm{p}$.

Beveridge, M.C.M. \& McAndrew, B.J. eds. (2000) Tilapias: Biology and Exploitation. Fish and Fisheries Series 25. Kluwer Academic Publishers, Dordrecht/Boston/London, pp. 360.

Buddington, R.K. (1980) Hydrolysis resistant organic matter as a reference for measurement of fish digestive efficiency. Trans. Am. Fish. Soc., 109, 653-656.
Cain, K.D. \& Garling, D.L. (1995) Pretreatment of soybean meal with phytase for salmonid diets to reduce phosphorus concentrations in hatchery effluents. Prog. Fish-Culturist, 57, 114-119.

Cao, L., Wang, W.M., Yang, C.T., Yang, Y., Diana, J.S., Yakupitiyage, A., Luo, Z. \& Li, D.P. (2007) Application of microbial phytase in fish feed. Enzyme Microb. Technol., 40, 497-507.

Forster, I., Higgs, D.A., Dosanjh, B.S., Rowshandeli, M. \& Parr, J. (1999) Potential for dietary phytase to improve the nutritive value of canola protein concentrate and decrease phosphorus output in rainbow trout (Oncorhynchus mykiss) held in $11{ }^{\circ} \mathrm{C}$ fresh water. Aquaculture, 179, 109-125.

Furuya, W.M., Gonçalves, G.S., Rossetto, V., Furuya, B. \& Hayashi, C. (2001) Phytase as feeding for Nile tilapia (Oreochromis niloticus): performance and digestibility. Rev. Brazil Zootech., 30, 924-929.

Harland, B.F. \& Oberleas, D. (1986) Anion-exchange method for determination of phytate in foods: collaborative study. J. AOAC Int., 69, 667-670.

Jackson, L., Li, M.H. \& Robinson, E.H. (1996) Use of microbial phytase in channel catfish Ictalurus punctatus diets to improve utilization of phytate phosphorus. J. World Aquac. Soc., 27, 309-313.

Jiang, J.L., He, J.H., Deng, J.P. \& Zhong, N. (2006) Advance in phosphorous equivalency of phytase. Feed Ind., 27, 47-51 (in Chinese).

Lall, S.P. (1991) Digestibility, metabolism and excretion of dietary phosphorus in fish. In: Nutritional Strategies and Aquaculture Waste (Cowey, C.B. \& Cho, C.Y. eds), pp. 21-36. University of Guelph, Guelph, ON.

Lanari, D., Agaro, E.D. \& Turri, C. (1998) Use of nonlinear regression to evaluate the effects of phytase enzyme treatment of plant protein diets for rainbow trout (Oncorhynchus mykiss). Aquaculture, 161, 345-356.

Latta, M. \& Eskin, M. (1980) A simple and rapid colorimetric method for phytate determination. J. Agric. Food Chem., 28, 13131315.

Li, M.H. \& Robinson, E.H. (1997) Microbial phytase can replace inorganic phosphorus supplements in channel catfish Ictalurus punctatus diets. J. World Aquac. Soc., 28, 402-406.

Liebert, F. \& Portz, L. (2005) Nutrient utilization of Nile tilapia Oreochromis niloticus fed plant based low phosphorus diets supplemented with graded levels of different sources of microbial phytase. Aquaculture, 248, 111-119.

Liener, I.E. (1994) Implications of antinutritional components in soybean foods. Crit. Rev. Food Sci. Nutr., 34, 31-67.

Lim, S.R., Choi, S.M., Wang, X.J., Kim, K.W., Shin, J.S., Min, T.S. \& Bai, S.C. (2004) Effects of dehulled soybean meal as a fish meal replacer in diets for fingerlings and growing Korean rockfish Sebastes schlegeli. Aquaculture, 231, 457-468.

NRC (National Research Council) (1993) Nutrient Requirements of Fish. National Academy Press, Washington, DC.

Oliva-Teles, A., Pereira, J.P., Gouveia, A. \& Gomes, E. (1998) Utilization of diets supplemented with microbial phytase by sea bass (Dicentrarchus labrax) juveniles. Aquat. Living Resour., 11, 255-259.

Onishi, T., Suzuki, M. \& Takeuchi, M. (1981) Changes in carp hepatopancreatic enzyme activities with dietary phosphorus levels. Bull. Jpn Soc. Sci. Fish., 47, 353-357.

Papatryphon, E., Howell, R.A. \& Soares, J.H. Jr (1999) Growth and mineral absorption by striped bass Morone saxatilis fed a plant feedstuff based diet supplemented with phytase. J. World Aquac. Soc., 30, 161-173. 
Plumb, J.A. (1999) Health Maintenance and Principal Microbian Diseases of Cultured Fishes. Iowa State University Press, Ames, IA, pp. 108-126.

Riche, M. \& Brown, P.B. (1996) Availability of phosphorous from feedstuffs fed to rainbow trout, Oncorhynchus mykiss. Aquaculture, 142, 269-282.

Riche, M., Trottier, N.L., Ku, P.K. \& Garling, D.L. (2001) Apparent digestibility of crude protein and apparent availability of individual amino acids in tilapia (Oreochromis niloticus) fed phytase pretreated soybean meal diets. Fish Physiol. Biochem., 25, 181-194.

Rodehutscord, M. (1996) Response of rainbow trout (Oncorhynchus mykiss) growing from 50 to $200 \mathrm{~g}$ to supplements of dibasic sodium phosphate in a purified diet. Aquaculture, 126, 328-331.

Rodehutscord, M. \& Pfeffer, E. (1995) Effects of supplemental microbial phytase on phosphorus digestibility and utilization in rainbow trout (Oncorhynchus mykiss). Water Sci. Technol., 31, 143-147.

Sajjadi, M. \& Carter, C.G. (2004) Effect of phytic acid and phytase on feed intake, growth, digestibility and trypsin activity in Atlantic salmon (Salmo salar, L.) . Aquac. Nutr., 10, 135-142.

Schäfer, A., Koppe, W.M., Meyer-Burgdorff, K.H. \& Günther, K.D. (1995) Effect of a microbial phytase on utilization of native phosphorus by carp in a diet based on soybean meal. Water Sci. Technol., 31, 149-155.

Simons, P.C., Versteegh, H.A., Jongbloed, A.W., Kemme, P.A. \& Slump, P. (1990) Improvement of phosphorus availability by microbial phytase in broilers and pigs. Br. J. Nutr., 64, 525-540.

Steele, R.G.D. \& Torrie, J.H. (1980) Principles and Procedures of Statistics, 2nd edn. McGraw-Hill, New York.

Storebakken, T., Shearer, K.D. \& Roem, A.J. (1998) Availability of protein, phosphorus and other elements in fishmeal, soyprotein concentrate and phytase-treated soy-protein concentratebased diets to Atlantic salmon, Salmo salar. Aquaculture, 161, 365-379.

Sugiura, S.H., Gabaudan, J., Dong, F.M. \& Hardy, R.W. (2001) Dietary microbial phytase supplementation and the utilization of phosphorus, trace minerals and protein by rainbow trout $O n c$ orhynchus mykiss (Walbaum) fed soybean meal-based diets. Aquac. Res., 32, 583-592.

Teskeredzic, Z., Higgs, D.A., Dosanjh, B.S., McBride, J.R., Hardy, R.W., Beames, R.M. \& Simell, M. (1995) Assessment of unphytinized and dephytinized rapeseed protein concentrate as sources of dietary protein for juvenile rainbow trout (Oncorhynchus mykiss). Aquaculture, 131, 261-277.

Vielma, J., Lall, S.P., Koskela, J., Schöner, F.J. \& Mattila, P. (1998) Effects of dietary phytase and cholecalciferol on phosphorus bioavailability in rainbow trout (Oncorhynchus mykiss). Aquaculture, 163, 309-323.

Vielma, J., Ruohonen, K. \& Peisker, M. (2002) Dephytinization of two soy proteins increases phosphorus and protein utilization by rainbow trout, Oncorhynchus mykiss. Aquaculture, 204, 145-156.

Vielma, J., Ruohonen, K., Gabaudan, J. \& Vogel, K. (2004) Topspraying soybean meal-based diets with phytase improves protein and mineral digestibilities but not lysine utilization in rainbow trout, Oncorhynchus mykiss (Walbaum). Aquac. Res., 35, 955-964.

Watanabe, T., Takeuchi, T., Murakami, A. \& Ogino, C. (1980) The availability to Tilapia niloticus of phosphorous in white fish meal. Bull. Jpn Soc. Sci. Fish., 46, 897-899.

Yan, W. \& Reigh, R.C. (2002) Effects of fungal phytase on utilization of dietary protein and minerals, and dephosphorylation of phytic acid in the alimentary tract of channel catfish Ictalurus punctatus fed an all-plant protein diet. J. World Aquac. Soc., 33, $10-22$.

Yoo, G.Y., Wang, X.J., Choi, S.M., Han, K.M., Kang, J.C. \& Bai, S.C. (2005) Dietary microbial phytase increased the phosphorus digestibility in juvenile Korean rockfish Sebastes schlegeli fed diets containing soybean meal. Aquaculture, 243, 315-322.

Yu, F.N. \& Wang, D.Z. (2000) The effects of supplemental phytase on growth and the utilization of phosphorus by crucian carp Carassius carassius. J. Fish. Sci. China, 7, 106-109 (in Chinese with English abstract). 